Finanse, Rynki Finansowe, Ubezpieczenia nr 4/2018 (94), cz. 1

DOI: $10.18276 /$ frfu.2018.94/1-09

s. $99-107$

\title{
The quality of information about business combinations under common control (BCUCC) disclosed under International Financial Reporting Standards (IFRS)
}

\section{Magdalena Janowicz}

\begin{abstract}
Purpose - The assessment of the quality of disclosures about BCUCC presented in financial statements of companies using IFRS.

Design/methodology/approach - Analysis of literature and legal regulations, content analysis, deductive and inductive reasoning.

Findings - The research results indicate the low quality of disclosure on the subject which may negatively affect the usefulness of information provided to the users.

Originality/value - The result of the research may be used to improve the current situation.
\end{abstract}

Keywords: legal mergers, financial statements, disclosure, public companies, IFRS/IAS

\section{Introduction}

The quality of the reporting information has been a subject widely discussed in literature. Patton and Verardo (2012) concluded that financial reports of an individual entity may, if their quality is good, provide valuable information about its peers and the entire economy, and in consequence allow for revising the expectations about their profitability. Kogut (2014) argued the importance of ethics in ensuring information quality, concluding that following accounting regulations did not guarantee achieving this aim and thus professional behaviour of accountants was necessary. Another research, conducted by X. Xing and S. Yan (2018), linked the improvement of accounting information quality with the decrease in systemic risk.

In general, reporting information must meet the requirements set in the Conceptual Framework (2010, sections QC4-QC34), i.e. possess certain qualitative characteristics: fundamental (relevance, faithful representation) and enhancing (comparability, verifiability, timeliness, understandability). As the quality of information may be assessed through these characteristics, and thus may be linked with its usefulness, they also are the subject of

* dr Magdalena Janowicz, Institute of Accounting, Faculty of Economics and Management, University of Szczecin, e-mail: magdalena.janowicz@usz.edu.pl. 
separate research. For example, Rówińska (2016) analysed the relevance of information in the context of the true and fair view concept and the agency theory, concluding that relevance is a subjective trait of information.

Gierusz and Martyniuk (2017) focused on a critical analysis of the comparability of financial statements and came to conclusion that this characteristic may attribute to the increase in the relevance and usefulness of information. A similar conclusion about the link between the comparability and usability of information was achieved by Garstecki (2014).

The usefulness of financial statements was also researched by Wójtowicz (2015). However, he ultimately focused on practical aspects of the information comparability, considering it to be one of the most important factors affecting the usefulness of information. At the same time Wójtowicz points out that comparability may be limited because IFRS and IAS allow to interpret the same events differently.

The usefulness of financial information becomes even more important in the case of events not regulated under IFRS, to which BCUCC belong. Where no guidance is provided for the accounting method and disclosures, meeting the expected quality requirements is a complicated and challenging process.

The aim of the paper is to assess the quality of information about BCUCC, presented in financial statements of Polish public companies preparing their financial statements in accordance with IFRS and International Accounting Standards (IAS). The authoress hypothesises that a lack of the standard disclosure list may affect the quality of financial reporting information.

The first part of the paper is a theoretical deliberation on the matter of what affects the scope of disclosure about BCUCC and what characteristics the information provided to users of financial statements should possess. The next part presents the methodology and the results of empirical research. The authoress analysed 28 sets of financial statements (consolidated and separate) of these Polish public companies which partook in BCUCC in 2016. The research methodology involved literature analysis, content analysis as well as deductive and inductive reasoning.

\section{Business combinations under common control in IFRS - the Polish experience}

To assure the satisfactory quality of information about economic events taking place in a reporting entity a required scope of disclosure is presented in the standard relating to the event, in case of business combinations by IFRS 3 (2008, sections B64-B66). As highlighted in the standard, it should provide information enabling users of the financial statement the evaluation of the nature and the effect that a business combination has had on the combined entity (IFRS 3, sections 60-61). 
However, BCUCC are not governed by IFRS 3 (2008, section 2). In their case IAS 8 should be applied instead. Applying this standard to BCUCC, the following options are available to the management of a combined entity (IAS 8, 2003, sections 10-12):

- IFRS 3 maybe be applied by analogy,

- the management may decide on applying a different approach, based on their professional judgment, assuming it will comply with the Conceptual Framework; it is possible but not necessary to use national GAAPs in such cases.

If the first option is used, the scope of disclosure is listed in IFRS 3 and should be followed by the combined company. However, the Polish Accounting Act (Acc. Act) provides regulations according to which in the cases not covered by IAS or IFRS, the Acc. Act must be applied instead (article 2[3]). This allows companies to account for BCUCC with the use of the purchase or pooling of interest method.

\section{Qualitative characteristics of financial information in the context of BCUCC}

The authoress is of the opinion that no matter which approach is used, the scope of disclosures about BCUCC should meet the general requirements set by IFRS 3 (sections 60-61) and the guidance provided by the Conceptual Framework. Whereas it could be assumed that the fundamental characteristics may be perceived as more important, the lack of comparability must affect the relevance of the provided information (Garstecki, 2014, p. 8). Extrapolating this line of thoughts it may be assumed that the lack of any enhancing quality will affect the realization of the fundamental traits.

Perhaps it is the easiest to explain how the faithful representation should be taken into consideration here. Presented information should be complete, neutral and free of errors. As BCUCC may take many forms (IASB, 2013, pp. 3-4), e.g. of a transfer of control between subsidiaries / a parent and a subsidiary or of a legal merger. There is no doubt that the method used to account for BCUCC should reflect the nature of the transaction. It may also be assumed that the condition of faithful representation is met if the appropriate mention is made in the financial statement and the method used to reflect this event is clearly stated.

It is possible that it is the complex nature of BCUCC that results in several methods of accounting that are applied in practice. Some of them use fair value, some others - carrying amounts taken either from a separate or consolidated financial statements. The rules are also applied differently. Sometimes they consider only the statements of financial positions of the combining companies, sometimes also income statements are considered (IASB, 2016, p. 4; Janowicz, 2017). This situation causes another problem, as save for the methods regulated by IFRS 3 or national GAAPs, there is no uniform scope of disclosure in existence. Instead it depends on the management what information is provided to the users of financial statements.

This number of methods used in practice strongly suggests that the comparability of financial statements may be in some way affected. With no authoritative guidance for the 
scope of disclosure it may become a debatable matter to what extent the reported information is understandable for its users. It is possible that verifiability is affected as well. The least debatable manner in this case is perhaps timeliness, as legal regulation require to prepare and sometimes announce financial statements within a certain period of time after the previous reporting period ended. Additionally, the matter of relevance may be brought and the problem of assessing which information is truly useful to the users.

Taking it all into consideration the authoress came to conclusion that the minimal scope of disclosure in case of methods of accounting not governed by IFRS 3, should at least provide information about:

- the parties taking part in the business combination,

- the reasons for the combination,

- the nature of the transaction (i.e. the description of the relation between the parties before the combination),

- the method of accounting and the explanation how it was used when necessary,

- the explanation how the business combination affected the financial statement.

\section{Empirical research - methodology and results}

To verify and complement the theoretical deliberation, the authoress conducted empirical research on a small sample of public companies. The sample for the analysis was non-random and consisted of these public companies which partook in BCUCC in 2016. Potential research objects were selected on the basis of current reports published by Polish public companies in years 2015-2016. As a result, 44 business combinations were identified.

Subsequently, financial statements for year 2016, prepared by the companies partaking in the business combinations, were collected to select these public companies which use IFRS and IAS to prepare both, their separate and consolidated financial statements. The final research sample consisted of 28 sets of financial statements of public companies which met both criteria.

The data from the financial statements provided information about 31 business combinations in total, out of which 30 (96.97\%) were BCUCC. Only BCUCC were considered in the further analysis, which rounds the number of business combinations to 30 .

The size of combining companies, their locations, legal form and type of their business activities do not determine the methods of accounting used and the disclosures made. Taking this matter into consideration, the research focused only on the information about BCUCC presented in the financial statements.

A detailed analysis of these documents pointed to a wider scope of information about BCUCC presented in the separate financial statements in comparison to the consolidated ones (23 sets of financial statements; $83.4 \%$ of the sample). In some cases, information about BCUCC presented in the consolidated statement was very limited (e.g. Orange Polska SA, Neuca SA), with one case where it was missing (Kopex SA). In five sets of the financial 
statements the scope of disclosure was the same. However, in one of them (Allerion SA) the information about BCUCC presented in the separate financial statement did not match the corresponding information in the consolidated statement (a difference in the numbers) ${ }^{1}$. It was also easier to understand the nature of this BCUCC while reading the consolidated financial statement.

This situation may raise a few questions:

- to what extent are BCUCC considered relevant information in general?

- to what extent is understandability assured by the provided information?

In case of Allerion SA the verifiability and faithful representation of financial information about BCUCC may also be questioned.

After careful analysis it became apparent that three business combinations (10\%) were accounted with the use of the acquisition method, however, in one case (Open Finance SA) the name of the method was mentioned in the consolidated financial statement only (Figure 1). In eleven BCUCC (37\%) the pooling of interest method was indicated. However, in at least three of these cases the use of the method is debatable as the carrying amounts were taken from the consolidated financial statements (e.g. Asseco SA). This approach resulted in transferring goodwill previously recognized in the consolidated financial statements to the separate ones. In another four cases (e.g. ZPUE SA) no information about the method used was provided in a separate financial statement and it was impossible to guess it on the basis of the disclosures made.

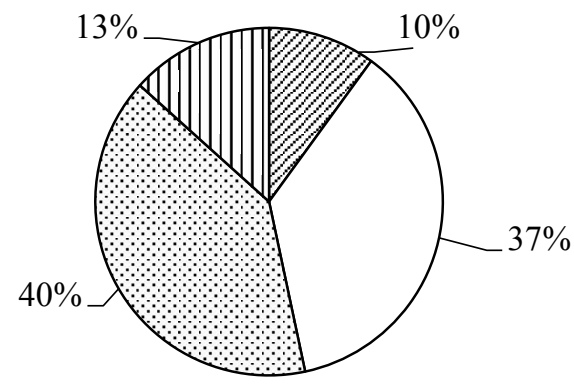

\section{$\square$ acquisition}

$\square$ pooling of interest

回other

凹 no data

Figure 1. Methods of accounting for business combinations used by the examined companies Source: own elaboration.

It should be noted that in a significant number of the business combinations some other methods of accounting were used. They are not named, usually described instead, and based on some version of carrying amounts, usually taken from the consolidated financial statements. For example, the disclosures indicated that only the statements of financial position were added together (e.g. Orange Polska SA) or, additionally, incomes and expenses of the

1 It is possible that the consolidated financial statement contained data on the acquisition date instead of on the day of legal merger, however, no explanation for the difference was provided. 
"acquiree" were included from the day of the legal merger. Another approach was consistent with accounting the business combination on the acquisition date and presenting the combined data in all elements of the financial statement. The comparative information was also adjusted to reflect the change (e.g. Kopex SA).

Summarising this part, it may be assumed that the number of used methods of accounting may strongly influence the comparability of the financial statements.

The authoress further concluded that if a company has chosen to follow the guidance provided by IFRS 3, the scope of disclosure should meet its requirements. However, the data collected in the research indicates that the disclosure was mostly minimal, providing only the most basic information. Out of the three companies that applied the standard, only one (Atal SA) provided almost satisfactory information, if the omissions which indeed focused on events that do not happen in all entities mean that these events did not take place. The information about BCUCC presented in the consolidated financial statement was not as extensive. It should also be noted that another company provided very limited information and only additional note from the consolidated statement made it clear what method of accounting was used (Open Finance SA). The issues with the financial statements of the third company (Allerion SA) was mentioned earlier.

Taking into consideration that the obligatory scope of disclosure was not fulfilled, it appears rather interesting that facultative information, mostly focused on legal aspects of the business combination, was also disclosed. This brings the question of what kind of information is considered relevant by the companies. The additional issues discovered during the research also question the fact if the disclosures made are neutral, complete and contain no errors (the aspects of faithful representation).

The matter is much more complicated in the case of these BCUCC where other methods were used due to the lack of an authoritative guidance on the scope of disclosures. Whereas it could be assumed that when the pooling of interest method is used, the disclosure should at least meet the requirements of the Accounting Act, the data gathered by the authoress do not confirm it being the case in practice. To assess quality of this information the authoress used the minimal, in her opinion, scope of disclosure (Table 1).

It should be noted that disclosures made are not limited to what is presented in the table and includes details about legal aspects of BCUCC. It may be debatable if this information is in fact relevant.

As previously mentioned, the scope of disclosure is wider in separate financial statements. It may be assumed that in most cases information provided in them is sufficient to make a conclusion about the effect that a BCUCC had on the financial statement. The authoress positively assesses the practice of including a separate part of the accounting policy, focussing on BCUCC. All this additional information may greatly increase understandability and verifiability. Whereas the number of methods used may in fact affect comparability between companies, information about the effect that BCUCC had on the financial statement may to a certain degree minimise the negative effect. However, in a few cases $(24 \%)$ some problems with comparability in time may also be observed. 


\section{Table 1}

Disclosures about BCUCC - the methods other than the acquisition method

\begin{tabular}{|c|c|c|c|c|c|}
\hline \multirow{3}{*}{ No. } & \multirow{3}{*}{ Disclosure } & \multicolumn{4}{|c|}{$\begin{array}{l}\text { The type of the financial } \\
\text { statement }\end{array}$} \\
\hline & & \multicolumn{2}{|c|}{ separate } & \multicolumn{2}{|c|}{ consolidated } \\
\hline & & obs. & $\%$ & obs. & $\%$ \\
\hline 1. & Information that a BCUCC took place & 25 & 100 & 24 & 96 \\
\hline 2. & $\begin{array}{l}\text { Information about the "acquiree" } \\
-\quad \text { the name } \\
- \text { the type of their business activities }\end{array}$ & $\begin{array}{l}25 \\
3\end{array}$ & $\begin{array}{l}100 \\
12\end{array}$ & $\begin{array}{l}24 \\
3\end{array}$ & $\begin{array}{l}96 \\
12\end{array}$ \\
\hline 3. & $\begin{array}{l}\text { The method of accounting: } \\
- \text { the name or description } \\
\text { - the detailed accounting policy for BCUCC }\end{array}$ & $\begin{array}{l}21 \\
10\end{array}$ & $\begin{array}{l}84 \\
40\end{array}$ & $\begin{array}{l}11 \\
7\end{array}$ & $\begin{array}{l}44 \\
28\end{array}$ \\
\hline 4. & The reasons for the combination & 10 & 40 & 6 & 24 \\
\hline 5. & $\begin{array}{l}\text { The nature of the transaction (a description of the relation between } \\
\text { the combining companies) }\end{array}$ & 15 & 60 & 9 & 36 \\
\hline \multirow[t]{3}{*}{6.} & $\begin{array}{l}\text { An explanation how the business combination affected the financial } \\
\text { statement, i.e.: }\end{array}$ & 18 & 62 & 2 & 8 \\
\hline & $\begin{array}{l}\text { a general effect on the financial statement (the change in main } \\
\text { positions of the financial statement) }\end{array}$ & & & & \\
\hline & $\begin{array}{l}\text { - detailed information in a form of the statement of financial } \\
\text { position (and income statement if applicable) with adjustments } \\
\text { made }\end{array}$ & 7 & 28 & 1 & 4 \\
\hline \multirow[t]{2}{*}{7.} & $\begin{array}{l}\text { Information about adjustments to the comparative financial } \\
\text { information, including: }\end{array}$ & 19 & 76 & 3 & 12 \\
\hline & - the statements where none was made & 6 & 24 & 1 & 4 \\
\hline
\end{tabular}

Notes: obs. - the number of observations.

Source: own elaboration.

In contrast, information presented in the consolidated statements is greatly limited. It could be argued that such omissions would be acceptable if such disclosures were found immaterial, however, no data to prove it exist. With this being the case, completeness, comparability, verifiability and understandability of the financial information may be affected.

\section{Conclusions}

The results of the conducted research may point to the fact that in many cases the quality of financial information provided about BCUCC may not meet the requirements. This situation also concerns these companies which declared the use of IFRS 3, which may lead to the conclusion that the existence of the authoritative guidance does not guarantee that all its requirements will be met. In the analysed group several methods of accounting were used, most of which are not governed by any regulation and thus lacking a direction on what 
should be disclosed in a financial statement. The scope of disclosures differed, depending on a company, and not always provided information that may be considered useful. It should also be noted that the consolidated financial statements were more likely to provide less information that the separate ones.

On the basis of the analysed data, the authoress concluded that in the case of separate financial statements the most problematic issue appeared to be comparability, however, additional disclosure may increase it. In one case additional issue of information not being complete, neutral and free of errors may also be raised, thus questioning to what extent this financial statement faithfully represents the transaction.

The situation becomes more complicated in the case of the consolidated financial statements. As the number of disclosures was significantly lower in them (and in one case completely omitted) verifiability and understandability were also affected.

Taking all these matters into consideration it becomes questionable to what extent the information about BCUCC was in fact useful for the users of the financial statements.

\section{References}

Garstecki, D. (2014). Porównywalność a przydatność sprawozdań finansowych. Analiza w ujęciu metodologii K.R. Poppera. Studia Oeconomica Posnaniensia, 2 (4), 7-22.

Gierusz, B., Martyniuk, T. (2017). Porównywalność informacji sprawozdawczych w świetle założeń koncepcyjnych MSSF. Finanse, Rynki Finansowe, Ubezpieczenia, 4 (88/1), 231-240. DOI: 10.18276/frfu.2017.88/122.

IASB (2013). Agenda Paper 14: Business Combinations under Common Control: Research Project Status Update. Retrieved from: http://www.ifrs.org (10.04.2018).

IASB (2016). Agenda Paper 23B: Business Combinations under Common Control: Application of the Predecessor Method. Retrieved from: http://www.ifrs.org (10.04.2018).

International Accounting Standard (IAS) 8. Accounting Policies, Changes in Accounting Estimates and Errors (2003). IFRS Foundation.

International Financial Reporting Standard (IFRS) 3. Business Combinations (2008). IFRS Foundation.

Janowicz, M. (2017). Business Combinations under Common Control in International Financial Reporting Standards - Is Authoritative Accounting Guidance Needed? Zeszyty Teoretyczne Rachunkowości, 93 (149), 97-111. DOI: 10.5604/01.3001.0010.3191.

Kogut, J. (2014). Etyka w rachunkowości a jakość sprawozdań finansowych. Prace Naukowe Uniwersytetu Ekonomicznego we Wrocławiu, 329, 161-171. 
Patton, A.J., Verardo, M. (2012). Does Beta Move with News? Firm-Specific Information flows and Learning about Profitability. The Review of Financial Studies, 25, 2789-2839.

Rówińska, M. (2016). Przydatność - podstawowa cecha informacji finansowej? Finanse, Rynki Finansowe, Ubezpieczenia, 2 (80/2), 517-523. DOI: 10.18276/frfu.2016.2.80/2-55.

The Accounting Act of 29 September 1994. Journal of Laws of 2018, item 395 as amended.

The Conceptual Framework For Financial Accounting (2010). IFRS Foundation.

Wójtowicz, T. (2015). Aspekty praktyczne użyteczności sprawozdań finansowych. Zeszyty Teoretyczne Rachunkowości, 82 (183), 167-180. DOI: 10.5604/16414381.1155823.

Xing, X., Yan, S. (2018). Accounting Information Quality and Systematic Risk. Review of Quantitative Finance and Accounting, 1-19. DOI: 10.1007/s11156-018-0703-z.

\section{JAKOŚĆ INFORMACJI O POŁĄCZENIACH JEDNOSTEK POD WSPÓLNĄ KONTROLĄ UJAWNIANYCH NA PODSTAWIE MIĘDZYNARODOWYCH STANDARDÓW SPRAWOZDAWCZOŚCI FINANSOWEJ}

Streszczenie: Cel - Ocena jakości ujawnień na temat połączeń spółek, prezentowanych w sprawozdaniach finansowych spółek publicznych stosujących MSSF.

Metodologia badania - Analiza literatury oraz aktów prawnych, analiza treści, metoda dedukcji oraz indukcji. Wynik - Badanie empiryczne wskazuje na niską jakość ujawnień na temat połączeń spółek, co może mieć negatywny wpływ na użyteczność informacji dostarczanych użytkownikom sprawozdań finansowych.

Oryginalność/wartość - Wyniki badania mogą być wykorzystane na potrzeby polepszenia bieżącej sytuacji.

Słowa kluczowe: połączenia spółek, sprawozdania finansowe, ujawnienia, spółki publiczne, MSSF/MSR

\section{Citation}

Janowicz, M. (2018). The quality of information about business combinations under common control (BCUCC) disclosed under International Financial Reporting Standards (IFRS). Finanse, Rynki Finansowe, Ubezpieczenia, 4 (94/1), 99-107. DOI: 10.18276/frfu.2018.94/1-09. 